DOI: $10.17805 /$ zpu.2016.1.31

\title{
Русский перевод важнейшего источника по югославянской истории
}

\author{
Г. А. ЕЛИСЕЕВ \\ (ИСТОРИКО-ПРОСВЕТИТЕЛЬСКОЕ ОБЩЕСТВО «РАДЕТЕЛЬ», Г. МОСКВА)
}

Рецензия на издание: Алексеев С. В. Летопись попа Дуклянина : перевод и комментарий. СПб. : Петербургское Востоковедение, 2015. 288 с. (Cер. Slavica Petropolitana). Ключевые слова: «Летопись попа Дуклянина»; история Балкан

$\mathrm{H}$ екоторые исторические памятники занимают особое положение в комплексе источников, освещающих прошлое той или иной страны. Это положение они приобрели в силу своей уникальности, нередко появляющейся из-за того, что от ранних периодов истории различных народов до нас просто не дошло иных подробных свидетельств. В нашей, русской, истории такое особое положение занимает «Повесть временных лет», а в истории южных славян - «Аетопись попа Ауклянина». Этот воистину исключительный памятник по истории Балкан наконец-то обрел полноценный и комментированный научный перевод на русский язык.

Текст к изданию подготовил известный отечественный специалист по истории славянских народов профессор, доктор исторических наук Сергей Викторович Алексеев. Его перу принадлежат научные биографии древнерусских князей Владимира Святого и Ярослава Мудрого, а также подробное исследование ранней истории славян «Славянская Европа». После различных переработок и дополнений в настоящее время это издание состоит из четырех томов, выпущенных издательством «Вече» в 2015 г. (Алексеев, 2015abcd). Особое значение среди исторических работ С. В. Алексеева имеет монография «Праславяне», посвященная предыстории славянства начиная со 2 тысячелетия до н. э. (Алексеев, 2015е). О «Аетописи попа Ауклянина» исследователь писал еще в монографии 2006 г. (Алексеев, 2006: 97-173). Однако издать перевод источника С. В. Алексееву удалось лишь сейчас. Книга вышла в издательстве «Петербургское Востоковедение», в серии «Slavica Petropolitana» (Алексеев, $2015 \mathrm{f}$ ).

При начальном знакомстве с этим историческим памятником легкое недоумение всегда вызывает его название, вызванное не очень удачным переводом с латинского языка на сербский в XIX в. Может быть, более академичным наименованием оказалось бы « Аетопись пресвитера из Аиоклеи», так как в упрощенном варианте, столь характерном для славянских языков, оно сейчас звучит несколько иронично и даже юмористически. Но изменить в этом случае что-либо невозможно, ведь историографическая традиция вот уже два века именует этот текст « $е$ етописью попа Ауклянина».

Хронологически летопись излагает события с VII по XII в., и уникальность ее специально подчеркивается публикатором-переводчиком: «Собственно югославянская историческая традиция о периоде VII-XII вв. представлена, по сути, единственным памятником - Аетописью попа Ауклянина. При всех спорах о происхождении Аетописи автор этих строк оценивает ее как памятник XII в., сохранившийся в латинском переводе со славянской Книги Готской» (там же: 11). Автор «Иетописи», судя по наблюдениям как самого С. В. Алексеева, так и его предшественников, основывался при создании текста не только на обширной фольклорной традиции, но и на несохранившихся славяноязычных исторических и агиографических сочинениях ( Книга "Мефодий”», «Житие св. Владимира»). 
В предисловии к публикации «Аетописи попа Ауклянина» читатели знакомятся с историей открытия памятника, а также с его достаточно сложной и противоречивой археографической судьбой. етопись в настоящее время существует в двух рукописных списках на латинском языке. Один из них хранится в Ватиканской библиотеке (Ватиканский список), другой - в Народной библиотеке Сербии (Белградский список). Обе рукописи относятся к XVII в. По указанию самого составителя летописи латинский текст - это только перевод с несохранившегося славянского варианта. Аля этого текста в науке предлагалось более адекватное (в том числе и точки зрения С. В. Алексеева) название: «Барский родослов», однако исторически закрепилось

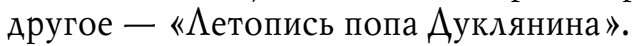

Этот памятник впервые была опубликован в итальянском переводе дубровчанином М. Орбини еще в 1601 г. (Il regno ..., 1601). Первое издание летописи на латыни подготовил в 1668 г. хорватский ученый И. Аучич. Впоследствии появлялись все новые и новые публикации как латинских оригиналов, так и переводов « лянина», однако перевода на русский язык до сих пор не существовало.

Затрагивает С. В. Алексеев в своем предисловии сложную и фактически неразрешимую проблему авторства текста летописи. (Она к тому же тесно увязана и с проблемой более раннего или более позднего происхождения этого памятника). Ученым до сих пор неясно - как же звали «попа Ауклянина»?

В наше время среди различных предположений о личности автора данного летописного текста выделяется гипотеза, предложенная в 2009 г. сербским ученым Т. Живковичем. Она выглядит следующим образом: «Т. Живкович вернулся к выводам С. Миюшковича о датировке памятника концом высокого Средневековья, относя его к началу XIV в. При этом исследователь попытался определить и точное время, и личность автора. Создание хроники связывалось им с именем барского архиепископа Рудгера. По версии Т. Живковича, это был выходец из Чехии, знакомый с большим количеством хроник XII-XIII вв. (от Козьмы Пражского до Гальфрида Монмутского). Он, как постулировалось, работал в рамках "политического проекта" славянодалматинской знати Сплита и Бара, причем “проект" так и остался нереализованным. Первоначальная сплитская редакция Аетописи будто бы качественно отражена в Хорватской хронике. Только завершающая часть памятника отражает славянский источник конца XI - начала XIII в.» (Алексеев, 2015f: 22). С. В. Алексеев не склонен поддерживать эту гипотезу, отмечая, что «никаких объективных данных, подтверждающих исторические занятия Рудгера, не имеется. Аля создания его "биографии" и обоснования своей точки зрения Т. Живкович доказывал тождество трех тезоименных персонажей церковной истории рубежа XIII и XIV вв.» (там же). Российский публикатор «Иетописи попа Ауклянина» справедливо считает, что современное состояние фактологической базы и источников, связанных с летописью, не позволяет уверенно говорить о ее возможном авторе.

Основная трудность, возникающая при чтении данного памятника даже в русском переводе, - это его лаконичность и малопонятность вне обширного исторического контекста. Этот контекст и создает для читателя С. В. Алексеев в своих подробных комментариях, занимающих бо́льшую часть изданной книги (там же: 83-273).

Одной из главных проблем комментирования оказывается краткость и невнятность некоторых сообщений летописи. Например, вот как выглядит 11 глава летописи: «Приняв королевство, Владислав, муж от природы сильный, позабыл Господа Бога своего и уклонился от путей отцов своих, не ходил право перед Господом, но за- 
пятнал себя множеством нечистот. Потому-то, выехав в один из дней на охоту, Божьим правосудием упал он в яму и умер» (там же: 55 ).

В этом случае комментатор оказывался пред сложной задачей - необходимо было дать дополнительные сведения о правлении князя Владислава и одновременно показать, как работал создатель летописного памятника, часто использовавший общие рассуждения или библейские аллюзии там, где ему не хватало информации. Это специально отмечает С. В. Алексеев: «Эта глава, как и предыдущая, в основном составлена из прямых библейских цитаций, однако имя описываемого “короля” на этот раз вполне историческое - Владислав. Очевидно, что его краткая “биография” строится на сознательном контрасте с его “отцом" Светоликом. Единственный князь по имени Владислав, известный в истории региона, - хорватский правитель IX в., преемник Борны. Однако известно о нем крайне мало» (там же: 159). Разобрав все доступные исторические сведения об этом правителе, С. В. Алексеев указывает: «Судя по

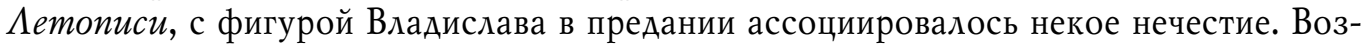
можно, речь идет о вероотступничестве. Ни подтвердить, ни опровергнуть эти припоминания нет никакой возможности. Нет возможности, конечно, и определить соотношение в них литературного трафарета и устной традиции» (там же). И особо автор комментария подчеркивает использование создателем "Аетописи попа Ауклянина» разных и разноречивых исторических традиций: «С Владислава “летописец” на коротком отрезке вновь использует хорватскую традицию. Злосчастный, по версии Иетописи, Владислав был введен как антитеза персонажу дуклянской традиции Светолику, также относящемуся к первым временам христианства в регионе. В оригинальной хорватской традиции (если Аетопись точно основывается на ней) он противопоставлялся своему предшественнику, принявшему христианство» (там же).

Чтобы понять, насколько подробны и основательны комментарии, сделанные С. В. Алексеевым, разберем еще один пример. В 12 главе « Аетописи» упоминается следующий исторический эпизод: «В правление Томислава венгерский король по имени Аттила двинул войска, чтобы побороть его. Но король Томислав был сильный, молодой и могучий воин, сходился с ним во множестве битв и всегда обращал его в бегство. Родил король Томислав сынов и дочерей и в 13-й год своего правления умер» (там же: 55 ).

Ясно, что ни с каким «королем Аттилой» в реальности бороться Томислав в годы своего правления (X в.) никак не мог. Комментатор разъясняет это сообщение летописца: «Вождь венгров именуется Аттилой. Аттила, гуннский вождь середины V в., как уже говорилось, действительно оставил след в истории Адриатического региона, и сохранение его имени в местной традиции неудивительно. Нет ничего странного и в связи Аттилы и венгров. Отождествление венгров с гуннами (основанное, в том числе, и на названии “хунгуры”, легшим в основу и славянского “угры”) возникло в европейской книжности почти сразу. Под влиянием этого отождествления - а возможно, и какихто собственных преданий - при венгерском королевском дворе Аттилу стали считать предком. Первое упоминание об этом относится к началу 1060-х гг., когда венгерская королева в благодарность за оказанную ее сыну помощь в обретении трона подарила “меч Аттилы” баварскому герцогу Отто... Таким образом, представление об Аттиле как предке венгерских королей уже к XII в. было хорошо известно за пределами Вен-

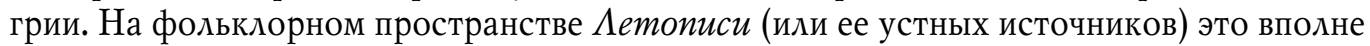
давало возможность встретиться с ним победителю венгров Томиславу» (там же: 162).

Одновременно С. В. Алексеев касается и других сомнительных подробностей правления Томислава, попутно анализируя специфические приемы создателя « Аетопи- 
си», применявшиеся им при работе с историческим материалом: «Томиславу $е т о-$ пись отводит 12-13-летний срок правления. С одной стороны, “в 13-й год своего правления умер" - отсылка к тем самым фольклорным “12 годам" (полным), которые уже приписывались Светолику. С другой стороны, и исторический Томислав мог править примерно 12 или 13 лет (ок. 914-926/7). Не стоит, наверное придавать этому преувеличенное значение. Хронология $\Lambda$ етописи по-прежнему остается фантастической, и появление рядом с Томиславом Аттилы - лишнее тому свидетельство... Нельзя, впрочем, не отметить, что с әтого момента “летописец" становится к хронологии более внимателен. Приводимые им сроки правления уже не настолько вызывающе сказочны, как раньше, тяготеют к “точности”. Но невозможно сказать, чего здесь больше. “Аетописец” мог основываться на родовых преданиях, по мере приближения к современности все более склонных считать годы (ср. скандинавские саги). Но мог он и намеренно играть в “достоверность” с целью придать ее сознательно фальсифицированной исторической схеме. Именно эта фальсификация - вольное соединение разнородных исторических традиций Хорватии, Сербии, Аукли - делает для нас в большинстве случаев невозможной сверку хронологических указаний» (там же: 162-163).

Читатель не получает просто «голую» информацию, а последовательно знакомится с взаимосвязью событий и источников того периода времени, которому посвящена конкретная глава «Аетописи попа Ауклянина». При этом С. В. Алексеев постоянно подчеркивает специфику «Цетописи», которая не только во многом основана на фольклорных материалах, но и отражает собственные взгляды ее создателя на историю, позволявшие ему весьма вольно обращаться с фактами. (Это точное наблюдение в то же время не отменяет важнейшего значения «Иетописи попа Ауклянина» для изучения югославянской истории в силу уже упоминавшейся ее исключительности).

Публикация перевода снабжена полноценным справочным аппаратом - указателями - именным, а также географических и этнических названий. При этом указатели привязаны не к страницам, а к разделам летописи, что существенно облегчает работу с ними. Также к тексту прилагаются карты-схемы, отражающие географический кругозор «попа Ауклянина» (карта № 1), показывающие Северные Балканы (карта № 2) и территорию Ауклянской державы в XI-XII вв. (карта № 3). В виде вклейки даны и сводные генеалогические таблицы - генеалогическая таблица Белоевичей (№ 1), генеалогическая таблица Воиславичей (№2) и генеалогическая таблица правителей загорской Сербии и их связей с Белоевичами-Воиславичами (№ 3). Это позволяет лучше ориентироваться как в тексте самой летописи, так и в подробных комментариях к ней. Специально автором перевода составлен и отдельный «Словарь социально-политической терминологии».

Аанная публикация окажется полезна и интересна не только специалистам, занимающимся историей южных славян или шире - историей Европы VII-XII вв., но и всем читателям, пожелавшим углубленно и непредвзято ознакомиться с ситуацией на Балканах в этот исторический период. Хотя препятствием для этого в наши кризисные времена может стать тираж книги - столь важный источник по истории южного славянства вышел тиражом всего лишь в 500 экземпляров.

\section{СПИСОК АИТЕРАТУРЫ}

Алексеев, С. В. (2006) Предания о дописьменной эпохе в истории славянской культуры XI-XV вв. М. : Изд-во Нац. ин-та бизнеса. 412 с.

Алексеев, С. В. (2015а) Заря славянства. V - первая половина VI в. М. : Вече. 288 с. 
Алексеев, С. В. (2015b) Славяне и авары. Вторая половина VI в. - начало VII в. М. : Вече. 256 с.

Алексеев, С. В. (2015c) Великое расселение славян. 602-679 гг. М. : Вече. 320 с.

Алексеев, С. В. (2015d) Славяне на пороге цивилизации. 679-800 гг. М. : Вече. 352 с.

Алексеев, С. В. (2015е) Праславяне: опыт историко-культурной реконструкции. М. : Академический проект. 430 с.

Алексеев, С. В. (2015f) Иетопись попа Ауклянина : перевод и комментарий. СПб. : Петербургское Востоковедение. 288 с. (Cep.: Slavica Petropolitana).

Il Regno de gli Slavi hoggi corrottamente detti Schiavoni (1601) / M. Orbini. Pesaro : Appresso Girolamo Concordia. 473 p.

Аата поступления: 15.12 .2015 г.

\section{AN IMPORTANT SOURCE ON THE HISTORY OF SOUTH SLAVS IN RUSSIAN TRANSLATION \\ G. A. ELISEEV \\ (RADETEL' Historical AND EDUCATIONAL SOCIETY)}

This is a review of: Alekseev S. V. Letopis' popa Duklianina : perevod i kommentarii [Chronicle of the Priest of Duklja: Translation and commentary]. St. Petersburg, Peterburgskoe vostokovedenie Publ., 2015. 288 p. (Series: Slavica Petropolitana).

Keywords: The Chronicle of the Priest of Duklja; Balkan history

\section{REFERENCES}

Alekseev, S. V. (2006) Predania o dopis'mennoi epokbe v istorii slavianskoi kul'tury XI-XV vv. [Legends of the preliterate era in the history of the Slavic culture of the the11th-15th centuries]. Moscow, National Institute of Business Publ. 412 p. (In Russ.).

Alekseev, S. V. (2015a) Zaria slavianstva. V-pervaia polovina VI v. [Dawn of the Slavs, the 5 th - first half of 6th century]. Moscow, Veche Publ. 288 p. (In Russ.).

Alekseev, S. V. (2015b) Slaviane $i$ avary. Vtoraia polovina VI v. - nachalo VII $v$. [The Slavs and Avars. The second half of the 6th - early 7 th c.]. Moscow, Veche Publ. 256 p. (In Russ.).

Alekseev, S. V. (2015c) Velikoe rasselenie slavian. 602-679 gg. [The great resettlement of the Slavs, 602-679]. Moscow, Veche Publ. 320 p. (In Russ.).

Alekseev, S. V. (2015d) Slaviane na poroge tsivilizatsii. 679-800 gg. [The Slavs at the threshold of civilization, 679-800]. Moscow, Veche Publ. 352 p. (In Russ.).

Alekseev, S. V. (2015e) Praslaviane: opyt istoriko-kul'turnoi rekonstruktsii [Pre-Slavs: An attempt at historical and cultural reconstruction]. Moscow, Akademicheskii proekt. 430 p. (In Russ.).

Alekseev, S. V. (2015f) Letopis' popa Duklianina : perevod $i$ kommentarii [The chronicle of the priest of Duklja: Translation and commentary]. St. Petersburg, Peterburgskoe vostokovedenie Publ. 288 p. (Series: Slavica Petropolitana). (In Russ.).

Il Regno de gli Slavi hoggi corrottamente detti Schiavoni [The Kingdom of the Slavs, or corruptly said Sclavoni] (1601) / M. Orbini. Pesaro, Appresso Girolamo Concordia. 473 p. (In It.).

Submission date: 15.12 .2015 .

Елисеев Глеб Анатольевич - кандидат исторических наук, доцент, руководитель исследовательской группы Историко-просветительского общества «Радетель». Адрес: 111395, Россия, г. Москва, ул. Юности, д. 5, корп. 3. Тел.: +7 (499) 374-55-81. Эл. aдpec: geliseev@mail.ru

Eliseev Gleb Anatolyevich, Candidate of History, Associate Professor, Head of Research Group, Historical and Educational Society "Radetel'". Postal address: Bldg. 3, 5 Yunosti St., 111395 Moscow, Russian Federation. Tel.: +7 (499) 374-55-81. E-mail: geliseev@mail.ru 